\title{
Morphofunctional effects of mitotane on mitochondria in human adrenocortical cancer cells
}

\author{
Giada Poli', Daniele Guasti ${ }^{2}$, Elena Rapizzi', Rossella Fucci', Letizia Canu', \\ Alessandra Bandinelli ${ }^{3}$, Nicoletta Cini ${ }^{3}$, Daniele Bani ${ }^{2}$, Massimo Mannelli ${ }^{1,4}$ \\ and Michaela Luconi ${ }^{1}$ \\ ${ }^{1}$ Endocrinology Unit, Department of Experimental and Clinical Biomedical Sciences, and ${ }^{2}$ Research Unit of Histology \\ and Embryology, Department of Experimental and Clinical Medicine, University of Florence, Viale Pieraccini 6, \\ 50139 Florence, Italy \\ ${ }^{3}$ Laboratorio Generale, Azienda Ospedaliero-Universitaria Careggi, Florence, Italy \\ ${ }^{4}$ Istituto Toscano Tumori, 50139 Florence, Italy
}

Correspondence should be addressed to M Luconi

Email

michaela.luconi@unifi.it

\begin{abstract}
At present, mitotane (MTT) represents the first-line pharmacological approach for the treatment of advanced adrenocortical carcinoma (ACC). Despite clear evidence that the drug can reduce the clinical signs of steroid excess in secreting ACC, the mechanism mediating the possible toxic effect of MTT on tumor cells still remains obscure. This study investigated the intracellular events underlying the toxic effect of MTT by studying qualitative and quantitative alterations in mitochondrial morphology and functions in human adrenocortical cancer cell lines, H295R and SW13. Increasing concentrations of MTT resulted in rapid intracellular accumulation and conversion of the drug. Cytostatic and cytotoxic effects were evident at doses corresponding to the therapeutic window $(30-50 \mu \mathrm{M})$ through an apoptotic mechanism involving caspase 3/7. Electron microscopic analysis of cell mitochondria displayed MTT-induced dose- and time-dependent alterations in the morphology of the organelle. These alterations were characterized by a marked swelling and a decrease in the number of respiratory cristae, accompanied by a significant depolarization of the mitochondrial membrane potential, finally leading to the disruption of the organelle. A drastic reduction of oxygen consumption was observed due to mitochondrial membrane damage, which was accompanied by a decrease in the levels of VDAC1 integral membrane channel. These findings contribute to better understand the intracellular mechanism of action of MTT in ACC cells, showing that its cytotoxic effect seems to be mainly mediated by an apoptotic process activated by the disruption of mitochondria.
\end{abstract}

\author{
Key Words \\ - adrenal cortex \\ - carcinoma \\ - intracellular signalling
}

Endocrine-Related Cancer (2013) 20, 537-550

\section{Introduction}

Adrenocortical carcinoma (ACC) is a rare and aggressive endocrine tumor with an incidence of $0.5-2$ cases per million people every year. ACC prognosis is mainly dependent on the stage at diagnosis (Fassnacht et al. 2009), with the overall 5-year survival rate being drastically reduced from $35 \%$ (Allolio \& Fassnacht 2006) to http://erc.endocrinology-journals.org DOI: 10.1530/ERC-13-0150
(C) 2013 Society for Endocrinology Printed in Great Britain
Published by Bioscientifica Ltd 
$5-10 \%$ if the mass is diagnosed at the advanced metastatic stage (Fassnacht et al. 2009). At present, the complete surgical removal of the tumor remains the most valuable option for ACC cure as most of the cytotoxic chemotherapeutic regimens proposed so far have displayed very limited efficacy. However, the use of the adrenotoxic agent mitotane (MTT or dichlorodiphenyldichloroethane (DDD)) as the first-line therapy, alone or in combined chemotherapy (Fassnacht et al. 2012), for advanced carcinoma as well as in adjuvant regimen (Terzolo et al. 2007) has been demonstrated to significantly enhance progression-free survival.

MTT (DDD), a derivative of the insecticide dichlorodiphenyltrichloroethane (DDT), has been successfully introduced for the treatment of Cushing's syndrome (Temple et al. 1969, Baudry et al. 2012) and lately for that of ACC (Metz 1973) due to its adrenotoxic effect: this therapeutic strategy results in an overall response in $25-30 \%$ of ACC patients (Hahner \& Fassnacht 2005). MTT metabolism and protein binding are species specific and higher in cattle and dogs than in humans as demonstrated in adrenal cortex homogenates (Cai et al. 1995a,b, Lindhe et al. 2002). Inhibition of steroidogenesis, in particular, of cortisol production, has been associated with the inhibition of specific enzymes responsible for cholesterol metabolism in the adrenal (StAR, P450scc, and CYP11B1; Asp et al. 2010, Lin et al. 2012). However, the mechanism underlying the adrenolytic activity of MTT has not yet been elucidated. Some early sporadic studies have reported the qualitative effects of MTT on animal adrenals (Kaminsky et al. 1962, Moore et al. 1980, Krüger et al. 1984) or on the human atypical estrogen-secreting adrenal cancer cell line Fang-8 (Fang 1979). Recently, by evaluating MTT-induced variation of the proteomic profile of the ACC H295R cell line (Stigliano et al. 2008), MTT has been suggested to interact with some proteins belonging to the classes of energetic metabolism, stress response, cytoskeletal structure, and tumorigenesis. Thus, the aim of the present study was to evaluate the potential toxic activity of MTT and its cellular targets in human cell models of ACC.

\section{Materials and methods}

\section{Materials}

Purified stereoisomers of MTT, o,p'-DDD (DDD), and of its metabolite dichlorodiphenyldichloroethylene (DDE), $\mathrm{o}, \mathrm{p}^{\prime}$-DDE (DDE), and of DDT, o, $\mathrm{p}^{\prime}$-DDT (DDT), were purchased from Sigma-Aldrich. 2-Propanol, $n$-hexane, acetonitrile, and water of HPLC grade were obtained from Panreac Quimica (Barcelona, Spain). All other reagents were procured from Sigma-Aldrich unless differently indicated.

\section{Cell cultures}

Human SW13 and H295R ACC cell lines (American Type Culture Collection, Manassas, VA, USA) were cultured in 10\% FBS (Euroclone, Pero, Milan, Italy)-DMEM/F-12 medium supplemented with $2 \mathrm{mM}$ L-glutamine, $100 \mathrm{U} / \mathrm{ml}$ penicillin, and $100 \mu \mathrm{g} / \mathrm{ml}$ streptomycin (Sigma-Aldrich) and enriched with a mixture of insulin/transferrin/ selenium for H295R cells.

Human primary fibroblasts were obtained from patients undergoing elective abdominal surgery, after getting written informed consent. The cells were cultured in 10\% FBS (Euroclone)-DMEM supplemented with $2 \mathrm{mM}$ L-glutamine, $100 \mathrm{U} / \mathrm{ml}$ penicillin, and $100 \mu \mathrm{g} / \mathrm{ml}$ streptomycin (Sigma-Aldrich) and used at passage 3.

For all the experiments, the cells were cultured for the indicated time under the indicated treatment with $1 \% \mathrm{FBS}$ at $37^{\circ} \mathrm{C}$ in a humidified $5 \% \mathrm{CO}_{2}$ atmosphere.

\section{HPLC measurement of intracellular levels of DDD and DDE}

Stock solutions ( $1 \mathrm{mg} / \mathrm{ml})$ of DDD and DDE were made up in methanol and stored at $4{ }^{\circ} \mathrm{C}$. Working solutions $(100 \mu \mathrm{g} / \mathrm{ml})$ were obtained by 1:10 dilution of the stock solutions in methanol. Standard solutions $(5,10$, and $20 \mu \mathrm{g} / \mathrm{ml}$ ) were prepared by adding 5,10 , and $20 \mu \mathrm{l}$ of the working solutions to $100 \mu \mathrm{l}$ of a serum-free solution respectively. To both the standard solutions and methanol-extracted cell samples, $100 \mu \mathrm{l}$ of the internal standard solution (o,p'-DDT, $20 \mu \mathrm{g} / \mathrm{ml}$ ) were added. All the samples and standards were subsequently extracted by adding $2 \mathrm{ml} n$-hexane and $2 \mathrm{ml}$ 2-propanol. After centrifugation at $2500 \boldsymbol{g}$ for $5 \mathrm{~min}$, the resultant supernatants $(4 \mathrm{ml})$ were evaporated to dryness under a nitrogen flow. The residues were resuspended with $60 \mu \mathrm{l}$ mobile phase, and $30 \mu \mathrm{l}$ were injected into the HPLC system (Chromsystems, München, Germany) equipped with a CLC300 isocratic pump, a CLC200 autosampler, and a SPD-20A/20AV u.v.-Vis detector (Shimadzu, Kyoto, Japan). Data acquisition and integration were performed using the Geminyx Software (Chromsystems). All the separations were achieved with a C18 reversed-phase column (ref. 24100, Chromsystems). The mobile phase consisted of an acetonitrile-water-phosphoric acid mixture $(85: 15: 0.05 \%$ ) delivered at a flow rate of $0.6 \mathrm{ml} / \mathrm{min}$, and the eluate was monitored at $218 \mathrm{~nm}$.

Published by Bioscientifica Ltd. 


\section{MTS assay}

The H295R cells were seeded in 96-well plates at a density of $1 \times 10^{4}$ cells/well. After $24 \mathrm{~h}$ of starvation, the cells were treated with vehicles (control) or increasing doses of MTT for the indicated times. Cell viability was assessed by 3-(4,5dimethylthiazol-2-yl)-5-(3-carboxymethoxyphenyl)-2-(4sulfophenyl)-2H-tetrazolium salt (MTS) assay (Promega), according to the manufacturer's instructions. The samples were analyzed using an ELISA plate reader (Victor ${ }^{3} 1420$, PerkinElmer, Monza, Italy) at $490 \mathrm{~nm}$ wavelength to measure optical density. Each experimental point was performed in quintuplicate in at least three independent experiments.

\section{DNA synthesis assay: $\left[{ }^{3} \mathrm{H}\right]$ thymidine uptake}

DNA synthesis was evaluated according to the amount of $\left[{ }^{3} \mathrm{H}\right] \mathrm{TdR}$ incorporated into trichloroacetic acid (TCA)precipitated materials. Cells grown in 10\% FBS complete medium till $70 \%$ confluence were starved for $24 \mathrm{~h}$ and then treated with increasing concentrations of MTT for $48 \mathrm{~h}$, pulsing them with $1.0 \mu \mathrm{Ci} / \mathrm{ml}\left[{ }^{3} \mathrm{H}\right] \mathrm{TdR}(6.7 \mathrm{Ci} / \mathrm{mmol}) 4 \mathrm{~h}$ before stopping proliferation in ice-cold 10\% TCA. After washing in TCA and then in methanol, the cells were solubilized in $0.2 \mathrm{M} \mathrm{NaOH}$, and radioactivity was measured using a scintillation counter. Experiments were performed in triplicate and repeated at least three times.

\section{Viable cell count}

The cells were seeded in 12 -well plates $\left(1 \times 10^{5}\right.$ cells/well $)$ and were treated with vehicles (control) or with increasing doses of MTT for the indicated times after $24 \mathrm{~h}$ of starvation. At each time interval, the cells were trypsinized and counted using a hemocytometer. Mean cell number was obtained by counting triplicates in three different experiments. Dead cells were excluded by trypan blue exclusion test.

\section{Transmission electron microscopy and morphometry of mitochondria}

H295R and SW13 cells cultured under different experimental conditions were pelleted by centrifugation, fixed in $4 \%$ glutaraldehyde, post-fixed in $1 \%$ osmium tetroxide, and embedded in Epon 812. Ultrathin sections were stained with uranyl acetate and alkaline bismuth subnitrate and examined under a JEM 1010 electron microscope (Jeol, Tokyo, Japan) at $80 \mathrm{kV}$. Micrographs were taken at $\times 10000$ and $\times 50000$ final magnifications using a
MegaView III digital camera (SIS-Soft Imaging System, Munster, Germany), and the ones obtained at the latter magnification were used for the morphometric analysis of mitochondria. Five cytoplasmic fields were randomly chosen in each experimental condition, for a total of about 20 mitochondrial profiles. Mitochondrial surface area and perimeter of cristae were measured using the iTEM image analysis software (SIS). Mitochondrial swelling/disruption was estimated by calculating the ratio of surface area to overall perimeter of cristae. Normal and swollen mitochondria were counted on at least five $\times 10000$ magnification micrographs for every sample.

\section{Evaluation of apoptosis by Muse cytofluorimetric analysis}

After $48 \mathrm{~h}$ of treatment with 30 and $50 \mu \mathrm{M}$ MTT, H295R and SW13 cells were analyzed for the detection of early and late apoptosis and cell death using Muse Annexin V/Dead Cell (cat \#MCH100105, Merck Millipore, Billerica, MA, USA) and Muse Caspase 3/7 (cat \#MCH100108, Merck Millipore) assays respectively, according to the manufacturer's instructions. Based on positivity for caspase 3/7 activity or phosphatidylserine exposure (positivity for annexin $\mathrm{V}$ ) in apoptotic cells and simultaneous detection of dead cells, positive for the nuclear dye 7-aminoactinomycin D (7-AAD), both assays enable to differentiate four populations in each sample by cytofluorimetric separation on a Muse automated cell analyzer (Merck Millipore): non-apoptotic live (lower left panel: 7-AAD negative, apoptosis negative), non-apoptotic dead (upper left panel: 7-AAD positive, apoptosis negative),

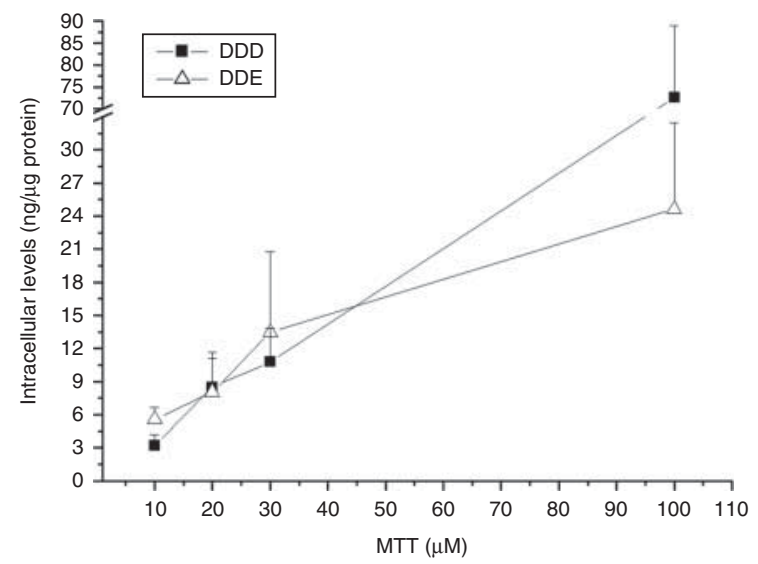

Figure 1

H295R cells capture and metabolize MTT. H295R cells were treated with increasing concentrations of MTT for $24 \mathrm{~h}$. After several washes, the cells were lysed in HPLC buffer and the concentrations of intracellular DDD and DDE were evaluated by HPLC. Data are expressed as mean \pm S.E.M. values. Experiments were performed in duplicates three times.

Published by Bioscientifica Ltd 
apoptotic live (lower right panel: 7-AAD negative, apoptosis positive), and apoptotic dead (upper right panel: 7-AAD positive, apoptosis positive) cells.
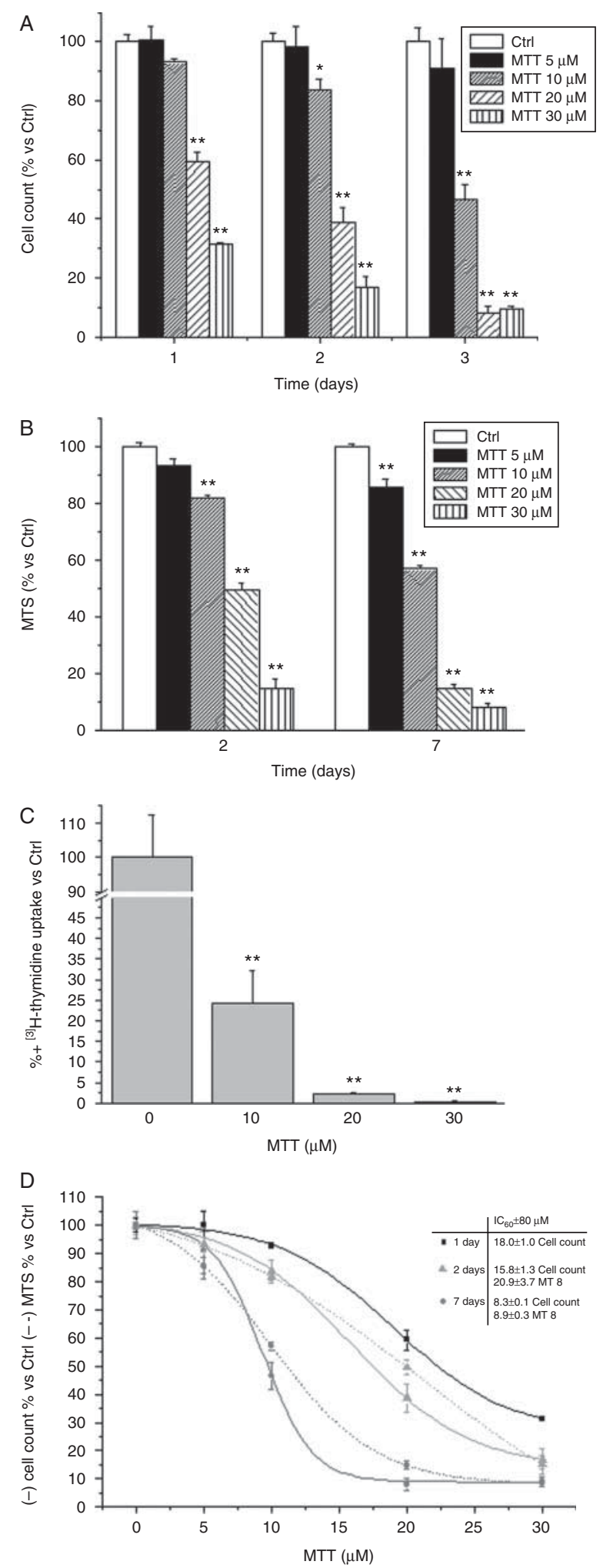

http://erc.endocrinology-journals.org DOI: 10.1530/ERC-13-0150

\section{Preparation of mitochondrial fraction}

The cells $\left(1 \times 10^{6}\right)$ were washed once with cold PBS, harvested by scraping with cold PBS, and centrifuged for $5 \mathrm{~min}$ at $800 \boldsymbol{g}$ at $4{ }^{\circ} \mathrm{C}$. The pellet was suspended in $0.5 \mathrm{ml}$ ice-cold medium (250 $\mathrm{mM}$ sucrose, $2 \mathrm{mM}$ HEPES, and $0.1 \mathrm{mM}$ EGTA, $\mathrm{pH}=7.4$ ), and the cells were disrupted by 40 passes in a homogenizer (tight-fitting). The homogenate was then centrifuged for $10 \mathrm{~min}$ at $800 \boldsymbol{g}$ at $4{ }^{\circ} \mathrm{C}$, and the mitochondria-rich supernatant was collected. The cell debris pellet was resuspended in a further $0.5 \mathrm{ml}$ of the same medium, homogenized, and centrifuged as described earlier. The two supernatants were pooled and centrifuged for $20 \mathrm{~min}$ at $13000 \mathrm{~g}$ at $4{ }^{\circ} \mathrm{C}$. The resulting mitochondrial pellet was suspended in $100 \mu \mathrm{l}$ medium containing $120 \mathrm{mM} \mathrm{KCl}, 20 \mathrm{mM}$ HEPES, $2 \mathrm{mM} \mathrm{MgCl}_{2}, 1 \mathrm{mM}$ EGTA, and $5 \mathrm{mg} / \mathrm{ml}$ BSA at $\mathrm{pH}=7.4$ (Kirby et al. 2007) and analyzed for oxygen consumption. Supernatants were quantified for protein content (Coomassie Blue reagent, Bio-Rad). All procedures were carried out on ice or at $4{ }^{\circ} \mathrm{C}$.

\section{Oxygen consumption analysis}

Quantification of oxygen consumption by mitochondria isolated from cells exposed or not exposed to different concentrations of MTT for 24 and $48 \mathrm{~h}$ was carried out using the Oxygraph system (Hansatech Instruments, Norfolk, UK). Mitochondria (300 $\mu \mathrm{g}$ ) were loaded into the chamber in $300 \mu \mathrm{l}$ respiration buffer $(125 \mathrm{mM} \mathrm{KCl}, 10 \mathrm{mM}$ Tris/MOPS, $10 \mathrm{mM}$ EGTA/Tris, and $1 \mathrm{mM}$ potassium phosphate monobasic, $\mathrm{pH}=7.4$ ) (Frezza et al. 2007).

\section{Estimation of mitochondrial membrane potential $(\Delta \psi \mathrm{m})$}

Mitochondrial membrane potential $(\Delta \psi \mathrm{m})$ was estimated in adherent live cells using the cationic, lipophilic dye

\section{Figure 2}

MTT inhibits cell viability and proliferation. H295R cells were grown in the presence or absence of increasing concentrations of MTT (5-30 $\mu \mathrm{M})$. After different time intervals, the cells were harvested and live cells were directly counted (A) or cell viability was estimated by the MTS assay (B). Cell proliferation was evaluated by thymidine incorporation (2-h pulse) in H295R cells treated or not treated with MTT (10-30 $\mu \mathrm{M})$ for $48 \mathrm{~h}$. Data are expressed as mean \% increase \pm s.E.M. of MTS absorbance (A), cell count (B), and thymidine incorporation (C) vs the respective controls in five experiments performed in quintuplicates or in triplicates respectively. Statistical analysis was performed with ANOVA followed by Dunnett's test: ${ }^{*} P<0.01$ and $* * P<0.0001$ vs the respective controls. Dose-response curves of cell viability and count obtained for the indicated time points in treated H295R cells as described above were used to calculate the respective MTT $\mathrm{IC}_{50}$ s indicated in the inset (D). MTT and cell count curves did not differ statistically significantly.

Published by Bioscientifica Ltd. 

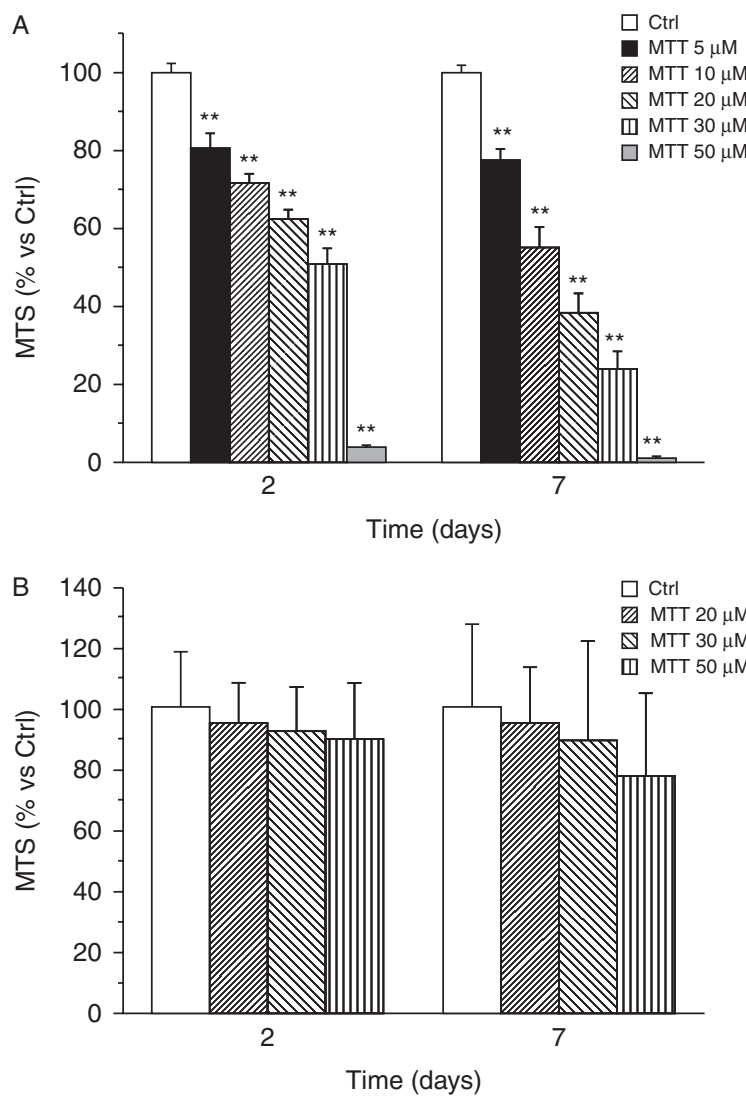

Figure 3

MTT toxic effect is specific for adrenocortical cancer. SW13 adrenocortical cancer cells (A) and primary fibroblasts (B) were grown in the presence or absence of increasing concentrations of MTT $(5-50 \mu \mathrm{M})$ for 2 and 7 days. After different time intervals, the cells were harvested and cell viability was estimated by the MTS assay. Data are expressed as mean \% increase \pm s.E.M. of MTS absorbance vs the respective controls in three experiments performed in triplicates. Statistical analysis was performed with ANOVA followed by Dunnett's test: $* * P<0.0001$ vs the respective controls.

JC-1 (5, 5',6,6'-tetrachloro-1,1', 3, $3^{\prime}$-tetraethylbenzimidazole carbocyanine iodide). For spectrofluorimetric detection, the cells were plated into 96 wells, whereas for fluorescence microscopy, they were plated on glass coverslips in six-well plates. After $48 \mathrm{~h}$ of treatment with different doses of MTT or $2 \mathrm{~h}$ of treatment with $10 \mu \mathrm{M}$ of valinomycin, the washed cells were incubated with a fresh culture medium containing $2.5 \mu \mathrm{g} / \mathrm{ml} \mathrm{JC}-1$ fluorescent dye for $30 \mathrm{~min}$ at $37^{\circ} \mathrm{C}$ in the dark. After washing in PBS, fluorescence intensities were measured at $527 \mathrm{~nm}$ (green) and $590 \mathrm{~nm}$ (red) wavelength emission on an ELISA plate reader (Victor ${ }^{3} 1420$, PerkinElmer). For fluorescence microscopy, coverslips were washed and mounted in an antifade mounting medium (Prolong Gold, Life Technologies Italia) on glass slides. The two-channel fluorescence emission was acquired with a Leica DM4000 epifluorescence microscope (Leica Microsystems GmbH, Wetzlar, Germany).

\section{Western blot}

The cells were lysed in RIPA buffer, and after protein measurement, equal amounts of proteins $(30 \mu \mathrm{g})$ for each sample were separated by SDS-PAGE and transferred onto PVDF membranes (Immobilon, Merck Millipore). Bound antibodies were revealed using ECL reagents (Immobilon, Merck Millipore) and analyzed on a Bio-Rad ChemiDoc Imaging System for dedicated chemiluminescent image acquisition (Imaging and Analysis Software by Bio-Rad, Quantity-One). The polyclonal anti-B subunit of succinate dehydrogenase (SDHB) antibody was obtained from Atlas Antibodies (Stockholm, Sweden). The polyclonal antiVDAC1 (sc-8828), anti-actin (sc-1615), and anti-caspase 3 (sc7272) primary antibodies and all the peroxidaseconjugated secondary antibodies were obtained from Santa Cruz Biotechnology.

\section{Statistical analysis}

Statistical analysis was performed using SPSS Software 18.0 version (SPSS, Inc.). One-way ANOVA followed by Dunnett's post hoc test was applied for multiple comparisons. A $P$ value $<0.05$ was considered statistically significant. Results are expressed as means \pm s.E.M. unless otherwise stated. On the basis of cell count and MTS curves using Origin Software 6.1 version (OriginLab Corporation, Northampton, MA, USA), 50\% inhibitory concentration $\left(\mathrm{IC}_{50}\right)$ of MTT was calculated.

\section{Results}

In order to demonstrate that MTT is metabolized not only in hepatocytes, but also locally in the adrenal tumor cells and is accumulated with its metabolites in the cells, we treated the ACC cell line H295R for $24 \mathrm{~h}$ with increasing doses of MTT and quantified DDD and its lipophilic metabolite DDE in the washed cell extracts by HPLC. Cell treatment with MTT $(10-100 \mu \mathrm{M})$ resulted in the detection of intracellular levels of DDD and DDE, which increased in parallel with the added doses of MTT (Fig. 1). Correspondently, MTT treatment resulted in a dose-related and time-dependent reduction in cell number, as demonstrated by the direct cell count (Fig. 2A). This reduction was due to a combined inhibitory effect on viability and proliferation, as evaluated by the MTS assay (Fig. 2B) and thymidine uptake at $48 \mathrm{~h}$ (Fig. 2C) respectively. Respective 

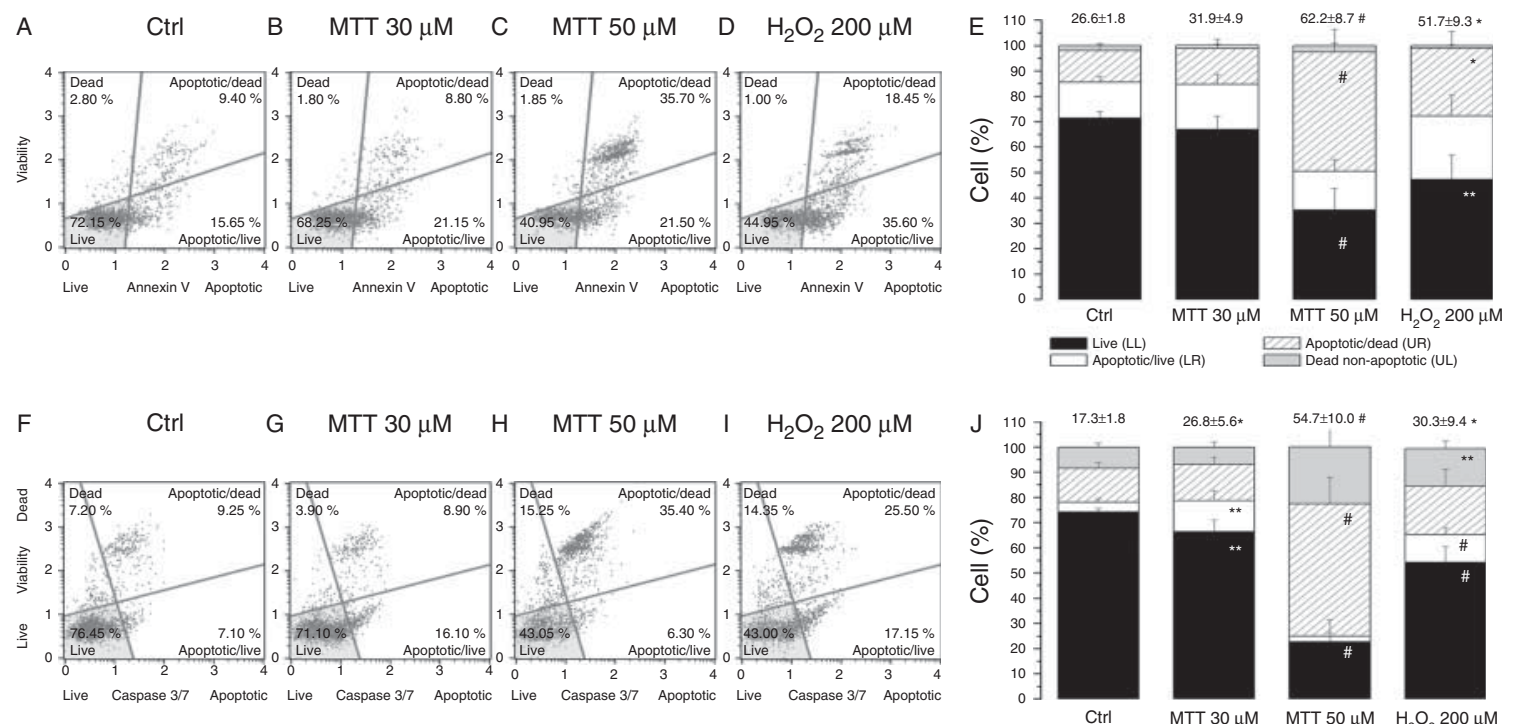

\section{Figure 4}

MTT induces apoptosis in adrenocortical cancer cells. After $48 \mathrm{~h}$ of treatment without ( $\mathrm{A}$ and $\mathrm{F}$ ) or with MTT of 30 (B and $\mathrm{G}$ ) and $50 \mu \mathrm{M}$ ( $\mathrm{C}$ and $\mathrm{H}$ ) as well as with $\mathrm{H}_{2} \mathrm{O}_{2}$ of $200 \mu \mathrm{M}$ (D and I), used as a positive control for the induction of apoptosis, H295R cells were trypsinized and analyzed with a Muse automated cell analyzer (Merck Millipore, Billerica, MA, USA) using Muse Annexin V/Dead Cell Assay (cat \#MCH100105, Merck Millipore), according to the manufacturer's instructions ( $A, B, C, D$ and $E$ ). Analogous independent experiments were analyzed with Muse Caspase-3/7 Assay (cat \#MCH100108, Merck Millipore), according to the manufacturer's instructions (F, G, H, I and J). Based on positivity for caspase 3/7 activity or phosphatidylserine exposure (positivity for annexin $\mathrm{V}$ ) in apoptotic cells and simultaneous detection of dead cells (7-AAD dye positivity), both assays enabled to differentiate four populations in each sample by cytofluorimetric separation on a Muse automated cell analyzer (Merck Millipore): non-apoptotic live (lower left (LL): 7-AAD negative, apoptosis

$\mathrm{IC}_{50}$, as calculated by the MTT inhibition curves for cell count and viability at the different time points, ranged between 10 and $20 \mu \mathrm{M}$ (Fig. 2D). The toxic effect exerted by MTT was also evident in the ACC cell line SW13 (Fig. 3A). Conversely, increasing doses of MTT up to $50 \mu \mathrm{M}$ did not significantly affect the cell viability of primary fibroblasts treated for comparable time intervals (Fig. 3B), suggesting the drug specificity for adrenal cancer cells.

Cytofluorimetric analysis of apoptotic events through the exposure of annexin V marker in the H295R cells (Fig. 4A, B, C, D and E) showed that 48 h of treatment with 30 and $50 \mu \mathrm{M}$ MTT stimulated a net increase in the percentage of total apoptotic cells compared with the controls. $\mathrm{H}_{2} \mathrm{O}_{2}$ was used as a positive control. Interestingly, at $48 \mathrm{~h}$, the effect of $30 \mu \mathrm{M}$ MTT was more evident in the live fraction of apoptotic cells (Fig. 4B (LR) and E), while higher doses mainly affected the dead fraction of apoptotic cells (Fig. 4C (UR) and E). The mean \pm s.e.m. negative), non-apoptotic dead (upper left (UL): 7-AAD positive, apoptosis negative), apoptotic live (lower right (LR): 7-AAD negative, apoptosis positive), and apoptotic dead (upper right (UR): 7-AAD positive, apoptosis positive) cells. Positivity for annexin $\mathrm{V}(\mathrm{A}, \mathrm{B}, \mathrm{C}, \mathrm{D}$ and $\mathrm{E})$ and caspase $3 / 7(F, G, H, I$ and $J$ ) activity helped in identifying early (apoptotic live fraction, LR) and late phases of apoptosis (apoptotic dead fraction, UR). Data obtained using the two kits were not completely superimposable due to the different markers used for the detection of apoptosis. Representative cytofluorimetric dot plots of four independent experiments performed for annexin $V(A, B, C$ and $D)$ or caspase $3 / 7(F, G, H$ and $I)$ detection. ( $E$ and J). Distribution of the mean \pm S.E.M. percentage of cells in the four populations identified with annexin $\mathrm{V}$ and caspase $3 / 7$ activity respectively. Inset, mean \pm S.E.M. total apoptosis \% is indicated for each population. Statistical analysis was performed with Student's $t$-test for independent data, $n=4 ;{ }^{*} P<0.05,{ }^{*} P<0.01$, and ${ }^{\#} P<0.001$ vs the respective controls.

increase in total apoptosis percentage was evident in response to MTT and $\mathrm{H}_{2} \mathrm{O}_{2}$ (Fig. 4E). These results were substantially confirmed by cytofluorimetric analysis performed using an apoptotic marker of later events in the apoptotic execution program, which evaluates caspase 3/7 activity (Fig. 4F, G, H, I and J). Figure 4J also reports the increase in the percentage of total apoptotic cells induced by 30 and $50 \mu \mathrm{M}$ MTT and $\mathrm{H}_{2} \mathrm{O}_{2}$ after $48 \mathrm{~h}$ of treatment. Similar results were also obtained in the SW13 cells (not shown).

To evaluate which intracellular structures are mainly affected by MTT treatment, we performed electron microscopy on H295R cells treated with increasing doses of MTT for $24 \mathrm{~h}$ (Fig. 5A, B, C, D, E, F, G and H) and with $10 \mu \mathrm{M}$ MTT up to 10 days (Fig. 5I, J, K, L, M, N, O and P). Electron microscopy clearly showed a progressive alteration in mitochondrial structure dependent both on the dose of MTT and on the length of treatment duration. Dose-related and time-dependent mitochondrial

Published by Bioscientifica Ltd. 

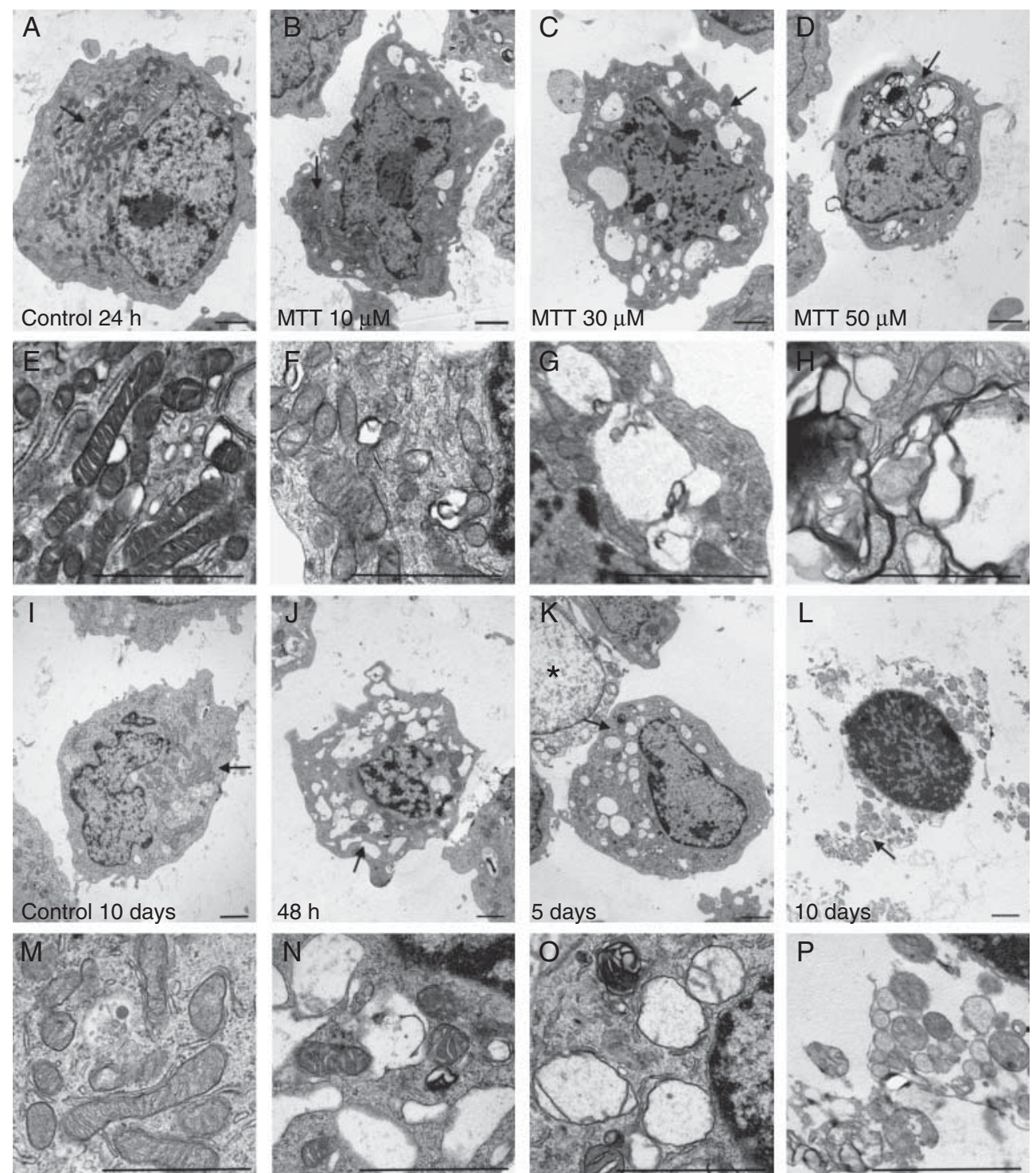

Figure 5

MTT treatment dose- and time-dependently affects mitochondrial morphology in H295R cells. (A, B, C, D, E, F, G and H) Representative electron micrographs of cells grown for $24 \mathrm{~h}$ in the absence or presence of increasing concentrations of MTT (10-50 $\mu \mathrm{M})$. The untreated 24-h control cells (Ctrl, A and E) showed rod-shaped mitochondria with numerous cristae and dense matrix. Conversely, in the MTT-treated cells, dose-related mitochondrial abnormalities were visible, consisting of prominent swelling, matrix clearing, and rarefaction and disruption of cristae. The most severe mitochondrial changes consisted of marked vacuolation containing electron-dense myelin-like remnants of the membranes (D and H). (I, J, K, L, $\mathrm{M}, \mathrm{N}, \mathrm{O}$ and $\mathrm{P}$ ) Representative electron micrographs of cells grown for different times in a culture medium to which MTT was added (10 $\mu \mathrm{M})$. Timerelated mitochondrial abnormalities $(\mathrm{J}, \mathrm{K}, \mathrm{L}, \mathrm{N}, \mathrm{O}$ and $\mathrm{P}$ ) were visible and

abnormalities were visible at different magnifications, consisting of prominent swelling and rarefaction of cristae and electron-dense myelin-like remnants of the inner mitochondrial membranes. Vacuolation of cytoplasm was

more pronounced than those observed at $24 \mathrm{~h}$ ( $\mathrm{B}$ and $\mathrm{F}$ ). At $48 \mathrm{~h}$ ( $\mathrm{J}$ and $\mathrm{N}$ ), mitochondrial swelling and disruption of cristae were the most evident changes; at 5 days ( $K$ and $O$ ), most mitochondria were swollen and often showed myelin-like membrane debris, while some cells appeared necrotic, with swollen nuclei and severely vacuolated cytoplasms (asterisk); at 10 days ( $L$ and $P$ ), almost all cells were lost, and the only ones present showed intermediate features between apoptosis and necrosis, such as hyperchromatic chromatin clumps typical of apoptotic nuclei and plasma membrane rupture typical of cell necrosis; mitochondria were barely recognizable as such. Control cells at 10 days of culture (I and M). Arrows indicate the cytoplasmic areas corresponding to the high-power panels $(E, F, G, H, M, N, O$ and $P)$. Bars $=1 \mu \mathrm{m}$.

evident and progressively worsened at high doses and longer treatment durations. At 5 days, most of the cells were lost due to the highly toxic effect of MTT and only dead cells were present, typically showing intermediate

Published by Bioscientifica Ltd. 

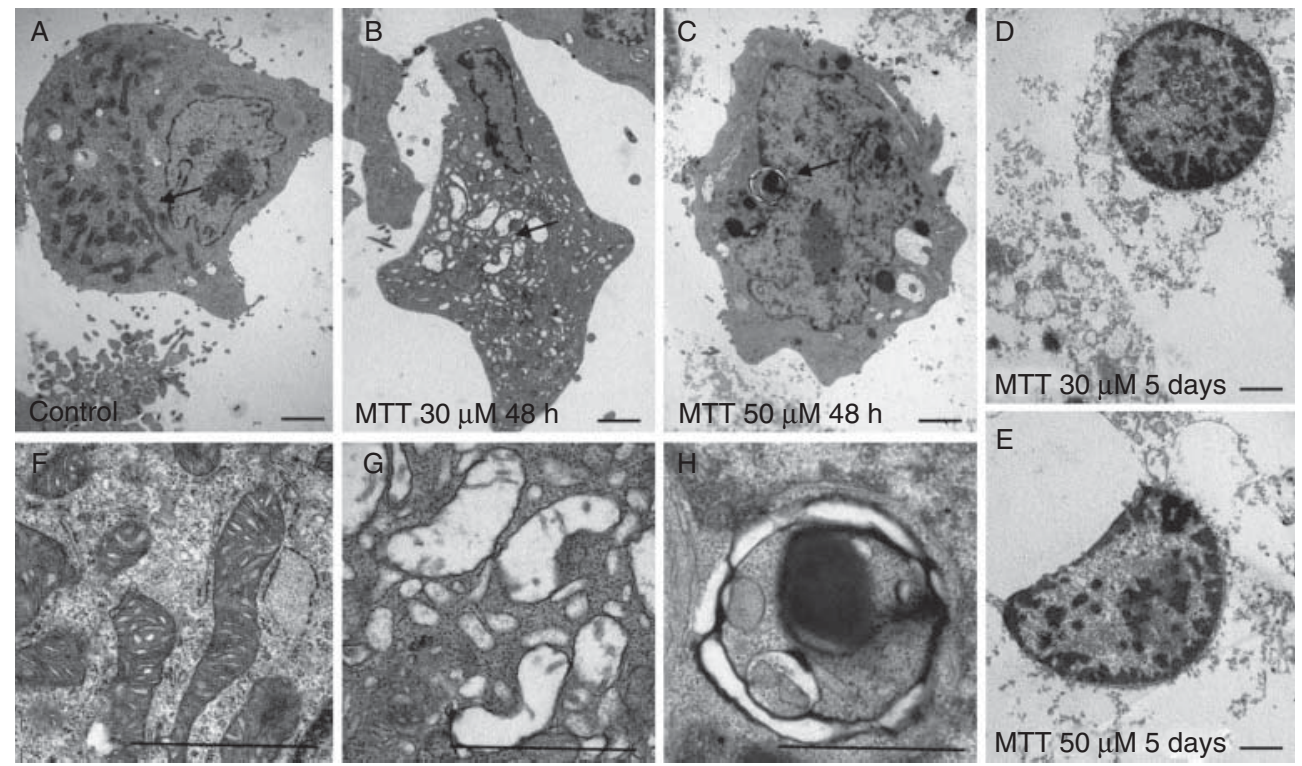

\section{Figure 6}

MTT treatment dose- and time-dependently affects mitochondrial morphology in SW13 cells. Representative electron micrographs of cells grown in a culture medium to which MTT was added at the noted concentrations and exposure times. Dose-related mitochondrial abnormalities consisting of swelling and disruption of cristae and cytoplasm vacuolation were visible ( $B, C, D, E, G$ and $H$ ). At 48 h, with a higher dose, mitochondria were no more recognizable as such, but appeared as myelin-

features between apoptosis and necrosis (aponecrosis), e.g. nuclear chromatin condensation and plasma membrane rupture; mitochondria were no more recognizable as such (Fig. 5I, J, K, L, M, N, O and P). Similar ultrastructural alterations following increasing doses and time of MTT treatment were detected in the SW13 cells (Fig. 6).

The total number of mitochondria decreased with increasing doses of MTT, showing a significant decrease in the number of normal mitochondria paralleled by a significant increase in that of swollen/disrupted ones (Figs 5 and 6), as also shown in Fig. 7A, at $48 \mathrm{~h}$ of MTT treatment. In order to better elucidate the nature of the mitochondrial lesions induced by MTT, we calculated the ratio of the whole area to the total length of the inner membrane cristae in individual mitochondria viewed by electron microscopy. Such a parameter takes into account both aspects of mitochondrial damage, i.e. mitochondrial swelling (increase in mitochondrial area) and decrease in the number and extension of the inner membrane cristae (decrease in the total length of cristae). This ratio significantly increased with increasing doses of MTT (Fig. 7B) and with the length of the treatment duration (Fig. 7C) in the H295R cells. Similar results were observed in the SW13 cells (not shown). like membrane aggregates $(C$ and $H)$; at 5 days ( $D$ and $E$ ), most cells were lost, and the remaining ones showed intermediate features between apoptosis and necrosis, such as hyperchromatic chromatin clumps typical of apoptotic nuclei and cytoplasmic clearing and disruption typical of cell necrosis. Control cells at 5 days of culture ( $A$ and $F$ ). Arrows indicate the cytoplasmic areas corresponding to the high-power panels ( $F, G$ and $H)$. Bars $=1 \mu \mathrm{m}$.

Since the reduction in the extension of inner cristae may affect mitochondrial functions, we next investigated whether the structural lesions also resulted in alterations in mitochondrial functions. Mitochondrial membrane potential $(\Delta \psi \mathrm{m})$ was estimated in adherent live cells using the cationic, lipophilic dye JC-1. Fluorescence microscopic analysis of H295R cells treated for $48 \mathrm{~h}$ with MTT resulted in a clear shift of the JC-1 molecule from red to green fluorescence (Fig. 8C and D). This shift was higher than that observed in the untreated control (Fig. 8A) and also more pronounced than that observed in the positive control, represented by 48-h valinomycin-treated cells (Fig. 8B). Quantitative analysis of fluorescence emission revealed a significant reduction in red fluorescence accompanied by an increase in green emission following MTT treatment (Fig. 8E), suggesting that MTT induced a reduction of mitochondrial membrane potential in the H295R cells.

We next evaluated whether the observed derangement of the mitochondrial membrane potential may affect mitochondrial respiration. Respiration was evaluated as inducible oxygen consumption in live mitochondria isolated from H295R cells treated or not treated for $48 \mathrm{~h}$ with increasing concentrations of MTT

Published by Bioscientifica Ltd 
$(10,30$, and $50 \mu \mathrm{M})$. Figure 9B shows mitochondrial oxygen consumption after addition of the respiratory substrate succinate. MTT strongly reduced oxygen consumption in a dose-dependent manner, with up to an $82 \pm 10 \%$ inhibition being obtained with $50 \mu \mathrm{M}$ MTT (Fig. 9A and B).

Since the reduced oxygen consumption observed in response to MTT treatment may be due to a general damage in the organization of the mitochondrial

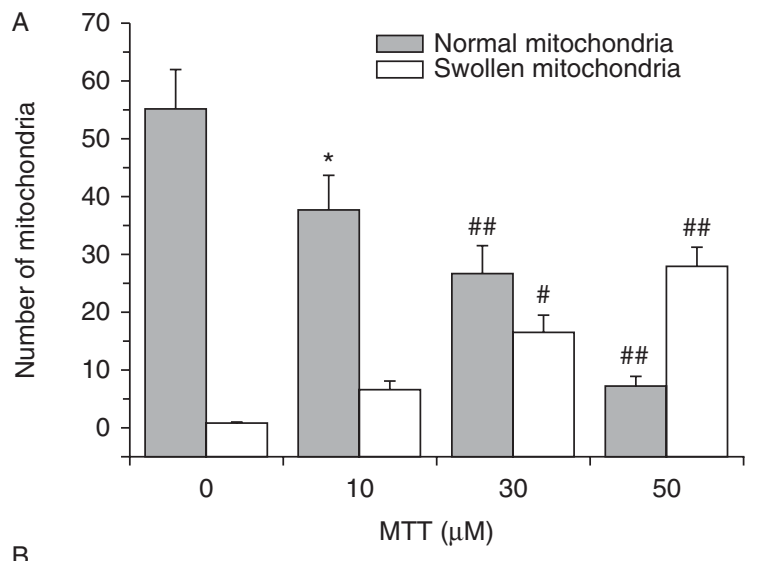

B

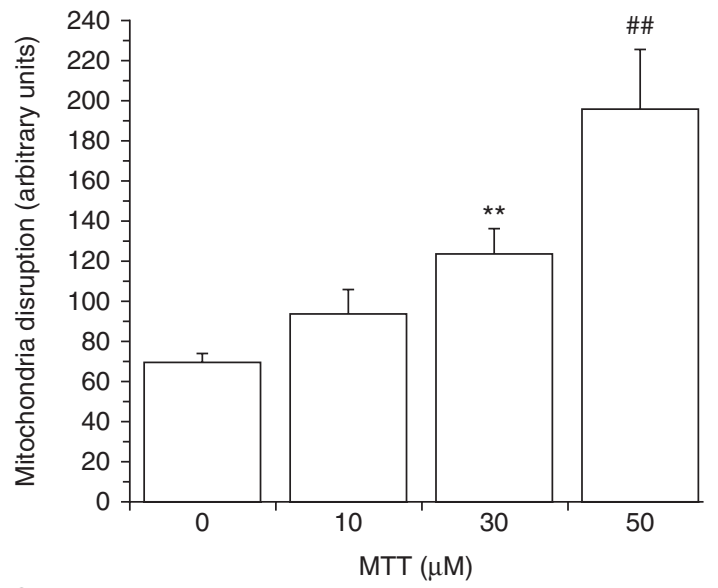

C

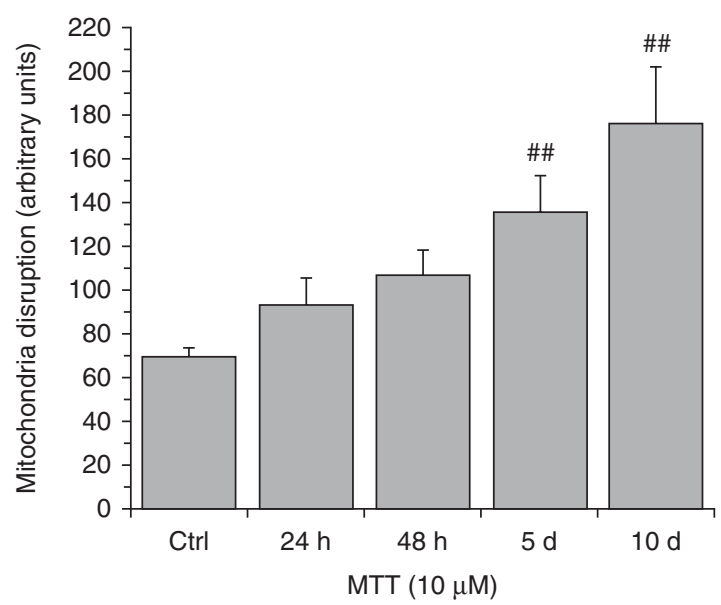

http://erc.endocrinology-journals.org DOI: 10.1530/ERC-13-0150 membranes and/or to a specific interference with the enzymes of the respiratory chain, we measured the effect of MTT on the expression of a structural channel in the outer membrane, the voltage-dependent anion channel, VDAC, and of one of the respiratory chain enzymes present in the inner mitochondrial membrane, SDH. Western blot analysis of total cell lysates showed that the levels of the SDHB remained rather stable after $48 \mathrm{~h}$ of MTT treatment (Fig. 10A and B). Conversely, the levels of VDAC were significantly reduced in a dose-dependent manner (Fig. 10A and B). In parallel, MTT increased the levels of cleaved caspase 3 (Fig. 10A and B), confirming the cytofluorimetric results obtained with the same $48 \mathrm{~h}$ of treatment with 30 and $50 \mu \mathrm{M}$ MTT (Fig. 4).

\section{Discussion}

MTT has long been used as the first-line chemotherapeutic agent for the treatment of patients affected by ACC, which represents a rare and aggressive neoplasm with poor prognosis (Metz 1973). Despite clear evidence that the drug can reduce the steroid excess in the secreting forms of ACC as well as in Cushing's syndrome, the mechanism underlying the possible toxic effect on human tumor cells still remains obscure. In this study, using H295R cell line as a model of human ACC, we demonstrated that MTT is actively taken up and metabolized by cancer cells, where it accumulates with its metabolites, as demonstrated by the detection of intracellular levels of DDD and DDE. In contrast to the hepatic biotransformation of MTT, which is mainly supported by microsomal P450 enzymes (Martz \& Straw 1980), in adrenals, mitochondria are the primary source of enzymes producing MTT metabolites

Figure 7

MTT induces quantitative morphometric alterations in H295R mitochondria. Quantitative morphometric analysis of mitochondria was performed on the electron micrographs of cells treated as described in Fig. 5 using a MegaView III digital camera (SIS-Soft Imaging System, Munster, Germany) according to procedures described in Material and methods section. Experiments were performed at least three times. (A) MTT treatment for $48 \mathrm{~h}$ induced a significant reduction in the number of normal mitochondria in parallel with a significant increase in that of swollen ones. Data are expressed as means \pm s.E.M. of normal and swollen mitochondria counted on at least five $\times 10000$ magnification micrographs for every sample. MTT treatment resulted in a morphological alteration in mitochondria consisting of increased total area and disruption of internal cristae, quantified as the ratio of mitochondrial area to the total length of the internal cristae (arbitrary units). Mean ratio \pm s.D. increased in a dose(48-h treatment, B) and time-dependent (C) manner. Statistical analysis was performed with ANOVA followed by Dunnett's test: ${ }^{*} P<0.05, * * P<0.01$, ${ }^{\#} P<0.005$, and ${ }^{\# \#} P<0.001$ vs the respective controls. 

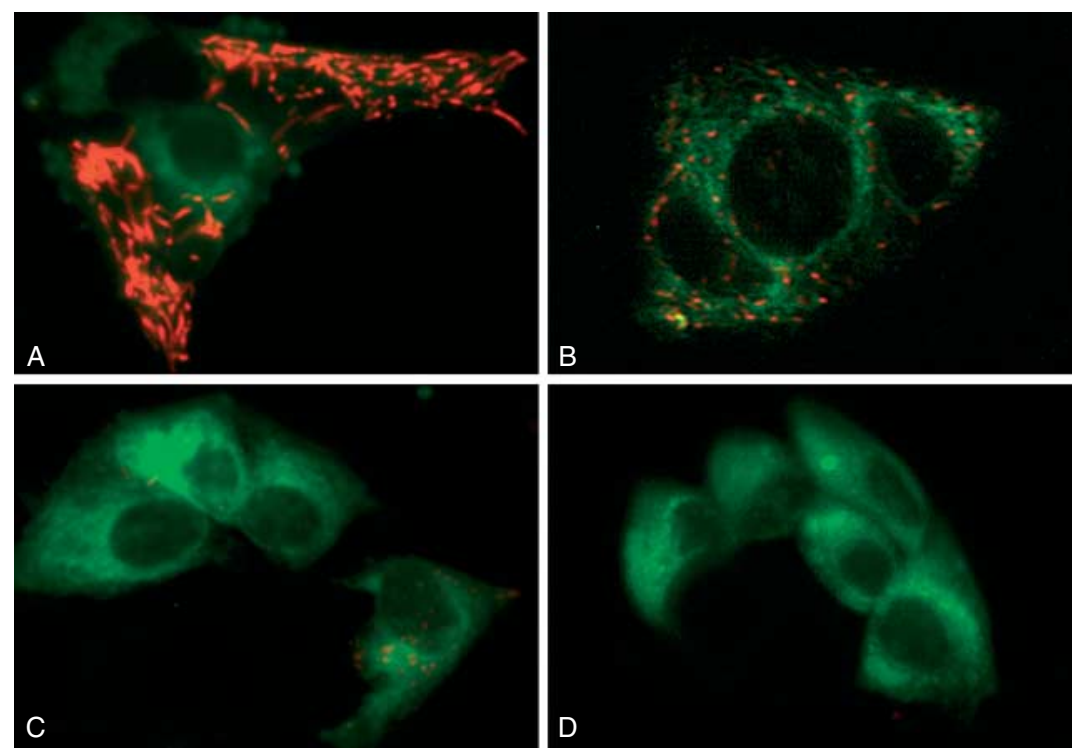

E

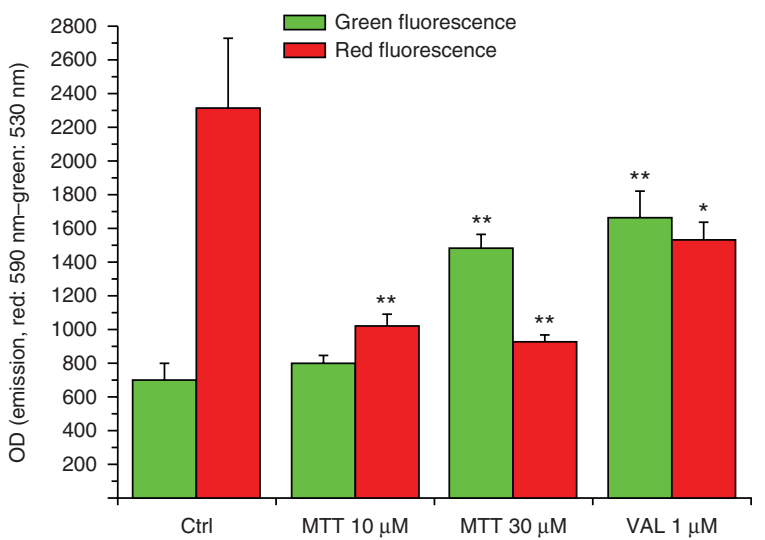

\section{Figure 8}

MTT treatment results in disrupted mitochondrial membrane potential $(\Delta \psi \mathrm{m})$ in $\mathrm{H} 295 \mathrm{R}$ cells. Cells were treated with different doses of MTT or with valinomycin (VAL), as a positive control, for $48 \mathrm{~h}$. Mitochondrial membrane potential $(\Delta \psi \mathrm{m})$ was estimated using the cationic, lipophilic dye JC-1 $\left(5,5^{\prime}, 6,6^{\prime}\right.$-tetrachloro-1, $1^{\prime}, 3,3^{\prime}$-tetraethylbenzimidazole carbocyanine iodide), which accumulated as red fluorescence-emission J-aggregates at high negative transmembrane potential in functional mitochondria or as diffused green fluorescence-emission monomers at low transmembrane potential in altered mitochondria. Epifluorescence microscopy of H295R cells not treated (A) or treated with $10 \mu \mathrm{M}$ MTT (C), $30 \mu \mathrm{M}$ MTT (D), or $1 \mu \mathrm{M}$

(Martz \& Straw 1977, 1980). In vitro experiments in adrenal cell lines and ex vivo experiments on adrenal slides (Cai et al. 1995b, Lund \& Lund 1995, Lindhe et al. 2002) have demonstrated that CYP11B1, in addition to its role in cortisol production, activates MTT and its metabolites through an initial hydroxylation step. Selective expression of this enzyme in the zona fasciculata and reticularis provides tissue specificity for MTT activation. Selective inhibition of CYP11B1 reduces the irreversible binding of
VAL (B) in a representative experiment. Merged images were obtained with excitation/emission of 490/530 $\mathrm{nm}$ for green fluorescence and 525/590 nm for red fluorescence. (E) Quantitative evaluation of red and green fluorescence emission. Data represent optical density (OD) mean \pm s.E.M. at the two emission wavelengths (530 and $590 \mathrm{~nm}$ for green and red fluorescence respectively) evaluated spectrofluorimetrically in at least six replicates for each sample in three independent experiments. Statistical analysis was performed with ANOVA followed by Dunnett's test: ${ }^{*} P<0.005$ and $* * P<0.001$ vs the respective red and green controls.

MTT and its metabolites to the proteic component of adrenal cells and adrenocortical tissue (Cai et al. 1995a, Lund \& Lund 1995, Lindhe et al. 2002). However, the relationship between this binding and the effect of MTT is yet to be established. Interestingly, there is a strict correlation between the variability in MTT activity in different species and the corresponding rank order of metabolic transformation/covalent binding. Bovine and canine adrenocortex seems to be the most sensitive to

Published by Bioscientifica Ltd. 

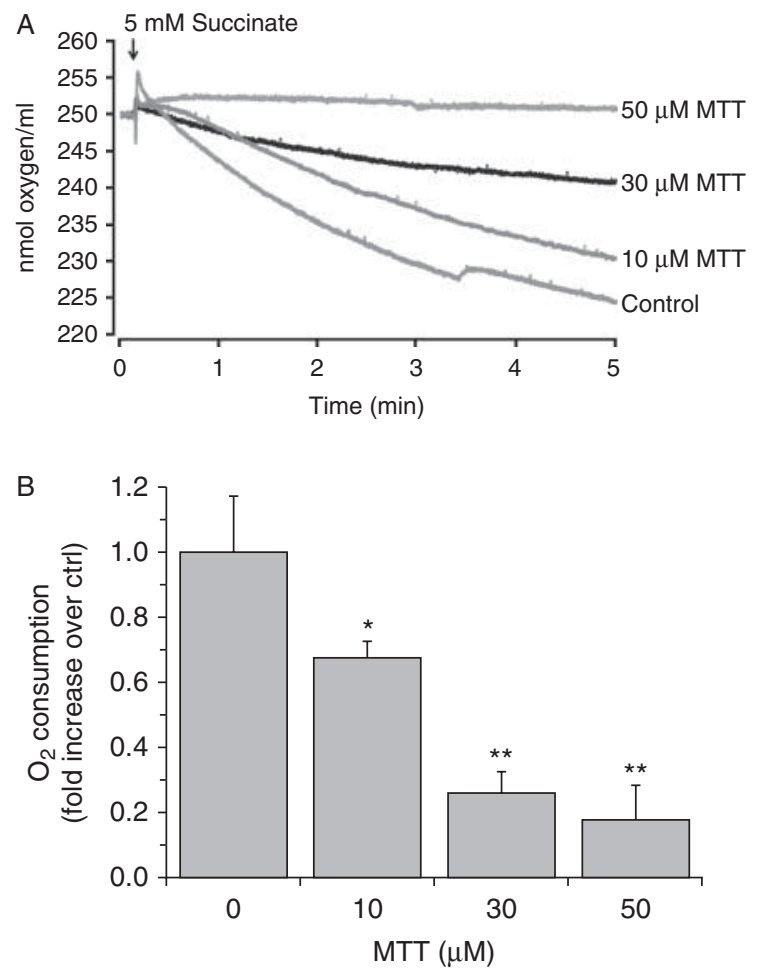

\section{Figure 9}

MTT induces a decrease in oxygen consumption in H295R cell-isolated mitochondria. (A) Representative experiment of the effects of $48 \mathrm{~h}$ of MTT treatment $(10,30$, and $50 \mu \mathrm{M})$ on oxygen consumption. Traces represent oxygen consumption during $5 \mathrm{~min}$ of respiration in live mitochondria $1 \mathrm{mg}$ of protein $/ \mathrm{ml}$ ) isolated from the different samples. The arrow indicates the time point when mitochondria were challenged with $5 \mathrm{mM}$ succinate. Respiration was monitored for $5 \mathrm{~min}$ at $37^{\circ} \mathrm{C}$. (B) Oxygen consumption expressed as mean fold increase \pm S.E.M. vs the controls (untreated cells) in four independent experiments. Statistical analysis was performed with ANOVA followed by Dunnett's test: $* P<0.05$ and $* * P<0.001$ vs the controls. In controls, endogenous oxygen consumption was $22 \pm 8 \mathrm{nmol}$ oxygen $/ \mathrm{ml}$, whereas it was $29 \pm 8 \mathrm{nmol}$ oxygen $/ \mathrm{ml}$ following succinate challenge.

the metabolism and effects of MTT in comparison with human normal and cancer tissue (Cai et al. 1995a,b). This relationship may explain the variability in the response to MTT observed in patients with adrenal cancer, depending on the ability of the tumor cell to metabolize and activate the drug (Schteingart 2007). The majority of data addressing the effects of MTT in adrenocortex report the inhibitory effect of this compound on steroidogenesis. In particular, mitochondrial enzymes, but not microsomal ones, in the steroidogenic pathways (StAR, CYP11A1, and CYP11B1) have been demonstrated to be inhibited in the H295 and H295R cells (Stigliano et al. 2008, Asp et al. 2010, Lin et al. 2012). Different strains of H295 cells have shown different degrees of inhibition in steroid secretion, depending on their steroidogenic profiles (Samandari et al. 2007). In contrast to the inhibitory effect on steroid production, the cytotoxic effects of MTT responsible for adrenal necrosis are less clear. Our data demonstrate that increasing concentrations of MTT, in the range of the therapeutic window $(14-20 \mathrm{mg} / \mathrm{l}$ corresponding to 43.7-62.5 $\mu \mathrm{M}$ MTT), result in cellular toxicity in H295R cells through the disruption of mitochondrial integrity and functions. Early studies have reported qualitative mitochondrial alterations in adrenals of animals treated with MTT (Kaminsky et al. 1962, Moore et al. 1980, Krüger et al. 1984) and in an estrogen-secreting human ACC cell line. Nevertheless, these effects were observed only at doses as high as $168 \mu \mathrm{M}$, whereas $80 \mu \mathrm{M}$ MTT was not effective on either mitochondrial structure or steroid secretion (Fang 1979). It may be hypothesized that low intracellular levels of MTT or short treatment durations affect primarily mitochondrial steroidogenic enzymatic activity with little effects on cellular viability (Stigliano et al. 2008, Lin et al. 2012). Conversely, higher doses of MTT or longer treatment durations cause a mitochondrial toxic effect, in addition to reduced steroid hormone secretion (Fang 1979, present paper), resulting in cell death (Cai et al. 1995b, present paper). Our data clearly show that MTT levels in the therapeutic window $(30-50 \mu \mathrm{M})$ exert a cytotoxic effect associated with the inhibition of cell proliferation. Increasing doses of MTT affected the normal morphology of H295R cell mitochondria starting from $24 \mathrm{~h}$ of incubation. Prolonged exposure to the drug up to 10 days enhanced the effect even at low doses $(10 \mu \mathrm{M})$. The MTT IC I $_{50}$ calculated for cell viability showed a substantial agreement among the MTS and cell count experiments (10-20 $\mu \mathrm{M}$ range), indicating that at the circulating therapeutic window of $14-20 \mathrm{mg} / \mathrm{l}$, MTT is largely exerting its ACC cytotoxic effect.

Electron microscopy shows that increasing doses of MTT result in a progressive reduction in the number of normal ellipsoidal mitochondria, inducing pronounced swelling and rounding of the profile, accompanied by clearing of the inner matrix, loss of respiratory cristae, and detachment of inner and outer mitochondrial membranes. At the highest doses and longest exposure times, most cells died, probably due to irreversible metabolic impairment. In fact, features typical of apoptosis, such as hyperchromatic nuclear bodies, co-existed with cytoplasmic disruption typical of necrosis. This phenomenon, previously termed 'aponecrosis', suggests that cells initiate the apoptotic process but cannot complete it because of energy deprivation and hence progress into necrosis (Formigli et al. 2002). To quantify the mitochondrial damage, we considered both swelling and loss of internal

Published by Bioscientifica Ltd. 
A

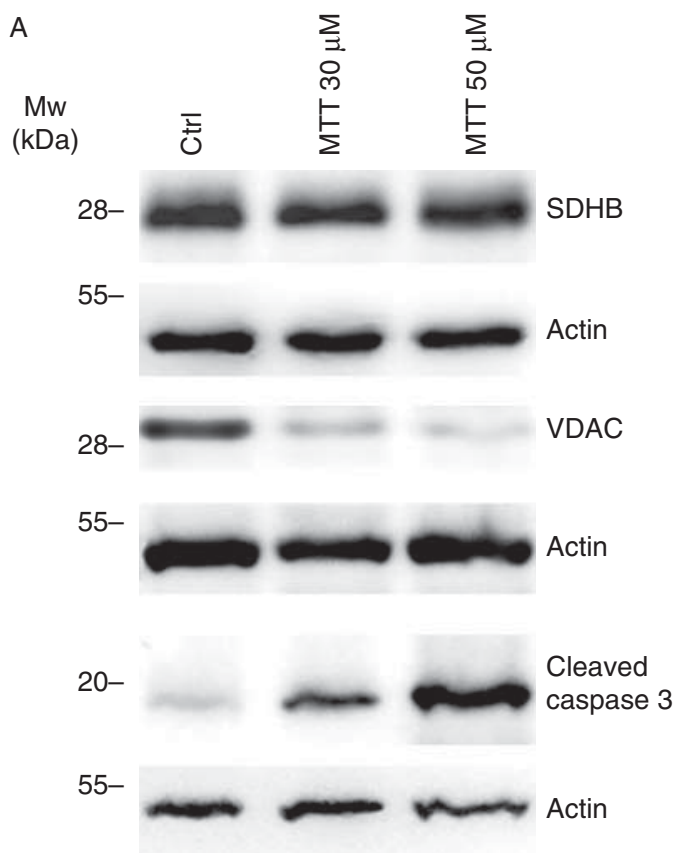

B

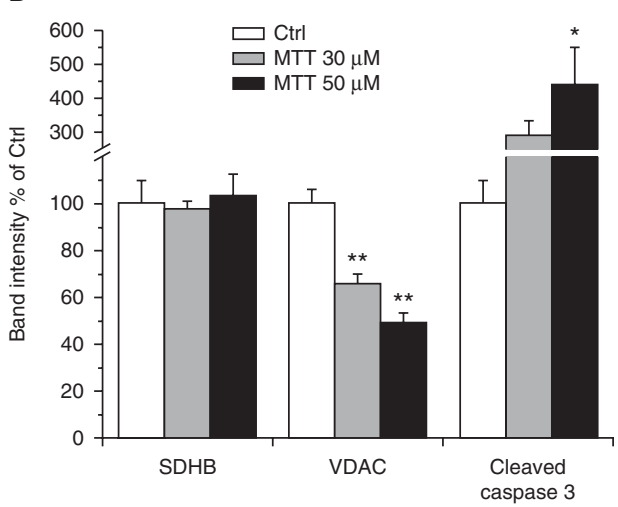

\section{Figure 10}

Effect of MTT on respiratory chain enzymes, structural proteins of the mitochondrial membranes, and caspase activity in H295R cells. (A) Representative western blot analysis of SDHB, VDAC, and cleaved caspase 3 proteins in H295R cells treated or not treated with 30-50 $\mu \mathrm{M}$ MTT for $48 \mathrm{~h}$. (B) Quantitative densitometric analysis of the expression of SDHB, VDAC, and cleaved caspase 3 normalized on that of actin as detected by western blot analysis in at least three independent experiments. Statistical analysis was performed with ANOVA followed by Dunnett's test: ${ }^{*} P<0.05$ and $* * P<0.001$ vs the respective controls.

cristae and calculated the ratio of the mitochondrial area to the total length of cristae in individual mitochondria of the analyzed cells. This parameter was closely related to the well-known morphological aspects of mitochondrial functions, i.e. number of cristae and density of the inner matrix, yielding more detailed information than other criteria adopted in previous studies, such as the percentage of the visible mitochondrial section displaying intact cisternae (Cadwell et al. 2008).
The effects of MTT are evident in both ACC cell lines, whereas in non-tumoral cells a slight but non-significant inhibition of viability can be detected only after long exposure with high doses. These findings suggest a specificity of MTT for adrenal cancer, which may justify that the side effects, although variable, seem to be restricted to gastric absorption and neurotoxicity.

The apoptotic images evidenced during electron microscopy have been confirmed by the cytofluorimetric analysis, demonstrating how MTT induces early (annexin $\mathrm{V}$ exposure at plasma membrane) as well as late apoptosis (caspase 3/7 activation) events.

The MTT-induced alterations in mitochondrial morphology are accompanied by a correspondent functional damage, as demonstrated by a progressive depolarization of mitochondrial membrane potential, finally resulting in the disruption of the respiratory machinery. In order to evaluate the effect of MTT on respiration in live mitochondria avoiding the detection of the toxic effect on the organelle, we measured oxygen consumption in the mitochondrial fraction after normalization for the number of mitochondria. In the treated cells, we observed a net reduction of oxygen consumption in the mitochondria-rich fraction (nearly $80 \%$ inhibition with $50 \mu \mathrm{M}$ MTT), which seems to be mainly due to a damage of the mitochondrial outer membrane (a significant decrease in the expression of VDAC is evident) rather than to a specific derangement of the respiratory chain complexes (stable levels of SDH). MTT has been previously demonstrated to downregulate the expression of proteins involved in cell redox potential, cholesterol trafficking, and stress response as well as in the maintenance of mitochondrial integrity (Stigliano et al. 2008). Reduction in the expression of VDAC1 following MTT treatment may not be only a passive consequence of the disruption of the mitochondrial ultrastructure and increased permeability of the outer membrane. Indeed, VDAC1, a voltage-dependent anion channel of outer membrane involved in regulation of metabolic and energy functions of mitochondria, has been more recently described as a key player in mitochondria-mediated programmed cell death and apoptosis (Zaid et al. 2005). Tumors highly overexpress VDAC, promoting hexokinase interaction and stimulation of cancer cell glycolysis (Mathupala \& Pedersen 2010). Downregulation of the expression of VDAC1 inhibits tumor cell growth both in vitro and in animal models (Koren et al. 2010), thus representing a novel potential anti-cancer target in tumor (Mathupala \& Pedersen 2010). VDAC1 also stabilizes StAR at the mitochondrial outer membrane, enabling the

Published by Bioscientifica Ltd. 
transport of cholesterol to the inner membrane to be converted to pregnenolone (Bose et al. 2008). Thus, reduction in the expression of VDAC1 may contribute to the steroidogenesis block observed in adrenal cancer cells and in ACC patients treated with MTT.

In conclusion, our findings contribute to better understand the intracellular mechanism of the action of MTT. We demonstrated that the drug significantly affects mitochondria in ACC cells and quantified the mitochondrial damage caused by MTT used at therapeutic doses. We also demonstrated that the cytotoxic effect of MTT implies the activation of the apoptotic process. Whether MTT has similar actions in the correspondent normal adrenocortex of patients under MTT treatment needs further investigation.

\section{Declaration of interest}

The authors declare that there is no conflict of interest that could be perceived as prejudicing the impartiality of the research reported.

\section{Funding}

ENS@T-Cancer: the research leading to the results reported herein received funding from the Seventh Framework Programme (FP7/2007-2013) under grant agreement no. 259735. This study was supported by the FIRB fund of the Italian Minister of University, Research and Instruction (protein number: RBAP1153LS)

\section{Acknowledgements}

We thank Dr R Felici and Prof. A Chiarugi (University of Florence) for their assistance in oxygen consumption experiments, Dr T Mello (University of Florence) for his help in fluorescence microscopic analysis, and Dr M Lulli (University of Florence) for providing the anti-caspase 3 antibody. L Canu, E Corsini, M Luconi, M Mannelli, G Poli, and E Rapizzi are members of the European Network for the Study of Adrenal Tumors (ENS@T).

\section{References}

Allolio B \& Fassnacht M 2006 Clinical review: adrenocortical carcinoma: clinical update. Journal of Clinical Endocrinology and Metabolism 91 2027-2037. (doi:10.1210/jc.2005-2639)

Asp V, Ullerås E, Lindström V, Bergström U, Oskarsson A \& Brandt I 2010 Biphasic hormonal responses to the adrenocorticolytic DDT metabolite 3-methylsulfonyl-DDE in human cells. Toxicology and Applied Pharmacology 242 281-289. (doi:10.1016/j.taap.2009.10.018)

Baudry C, Coste J, Bou Khalil R, Silvera S, Guignat L, Guibourdenche J, Abbas H, Legmann P, Bertagna X \& Bertherat J 2012 Efficiency and tolerance of mitotane in Cushing's disease in 76 patients from a single center. European Journal of Endocrinology 167 473-481. (doi:10.1530/ EJE-12-0358)

Bose M, Whittal RM, Miller WL \& Bose HS 2008 Steroidogenic activity of StAR requires contact with mitochondrial VDAC1 and phosphate carrier protein. Journal of Biological Chemistry 283 8837-8845. (doi:10.1074/jbc.M709221200)
Cadwell K, Liu JY, Brown SL, Miyoshi H, Loh J, Lennerz JK, Kishi C, Kc W, Carrero JA, Hunt S et al. 2008 A key role for autophagy and the autophagy gene Atg1611 in mouse and human intestinal Paneth cells. Nature 456 259-263. (doi:10.1038/nature07416)

Cai W, Benitez R, Counsell RE, Djanegara T, Schteingart DE, Sinsheimer JE \& Wotring LL 1995a Bovine adrenal cortex transformations of mitotane [1-(2-chlorophenyl)-1-(4-chlorophenyl)-2,2-dichloroethane; $\mathrm{o}, \mathrm{p}^{\prime}$-DDD] and its p,p'- and m,p'-isomers. Biochemical Pharmacology 49 1483-1489. (doi:10.1016/0006-2952(95)00028-X)

Cai W, Counsell RE, Djanegara T, Schteingart DE, Sinsheimer JE \& Wotring LL $1995 b$ Metabolic activation and binding of mitotane in adrenal cortex homogenates. Journal of Pharmacological Sciences 84 134-138. (doi:10.1002/jps.2600840203)

Fang VS 1979 Cytotoxic activity of 1-(o-chlorophenyl)-1-(p-chlorophenyl)2,2-dichloroethane (mitotane) and its analogs on feminizing adrenal neoplastic cells in culture. Cancer Research 39 139-145.

Fassnacht M, Johanssen S, Quinkler M, Bucsky P, Willenberg HS, Beuschlein F, Terzolo M, Mueller HH, Hahner S \& Allolio B 2009 Limited prognostic value of the 2004 International Union Against Cancer staging classification for adrenocortical carcinoma: proposal for a revised TNM classification. Cancer 115 243-250. (doi:10.1002/cncr. 24030)

Fassnacht M, Terzolo M, Allolio B, Baudin E, Haak H, Berruti A, Welin S, Schade-Brittinger C, Lacroix A, Jarzab B et al. 2012 FIRM-ACT Study Group: combination chemotherapy in advanced adrenocortical carcinoma. New England Journal of Medicine 366 2189-2197. (doi:10.1056/ NEJMoa1200966)

Formigli L, Zecchi Orlandini S, Capaccioli S, Poupon MF \& Bani D 2002 Energy-dependent types of cell death in MCF-7 breast cancer cell tumors implanted into nude mice. Cells, Tissues, Organs 170 99-110. (doi:10.1159/000046184)

Frezza C, Cipolat S \& Scorrano L 2007 Organelle isolation: functional mitochondria from mouse liver, muscle and cultured fibroblasts. Nature Protocols 2 287-295. (doi:10.1038/nprot.2006.478)

Hahner S \& Fassnacht M 2005 Mitotane for adrenocortical carcinoma treatment. Current Opinion in Investigational Drugs 6 386-394.

Kaminsky N, Luse S \& Hartroft P 1962 Ultrastructure of adrenal cortex of the dog during treatment with DDD. Journal of the National Cancer Institute 29 127-159.

Kirby DM, Thorburn DR, Turnbull DM \& Taylor RW 2007 Biochemical assay of the respiratory chain complex activity. Methods in Cell Biology 80 93-119.

Koren I, Raviv Z \& Shoshan-Barmatz V 2010 Downregulation of voltagedependent anion channel-1 expression by RNA interference prevents cancer cell growth in vivo. Cancer Biology \& Therapy 9 1046-1052. (doi:10.4161/cbt.9.12.11879)

Krüger R, Uhl UJ \& Voigt KH 1984 Fine structural effects of a DDT derivative on a rat adrenocortical carcinoma. Histochemical Journal 16 406-408. (doi:10.1007/BF01002862)

Lin CW, Chang YH \& Pu HF 2012 Mitotane exhibits dual effects on steroidogenic enzymes gene transcription under basal and cAMPstimulating microenvironments in NCI-H295 cells. Toxicology 298 14-23. (doi:10.1016/j.tox.2012.04.007)

Lindhe O, Skogseid B \& Brandt I 2002 Cytochrome P450-catalyzed binding of 3-methylsulfonyl-DDE and o,p'-DDD in human adrenal zona fasciculata/reticularis. Journal of Clinical Endocrinology and Metabolism 87 1319-1326. (doi:10.1210/jc.87.3.1319)

Lund BO \& Lund J 1995 Novel involvement of a mitochondrial steroid hydroxylase (P450c11) in xenobiotic metabolism. Journal of Biological Chemistry 270 20895-20897. (doi:10.1074/jbc.270.36.20895)

Martz F \& Straw JA 1977 The in vitro metabolism of 1-(o-chlorophenyl)-1(p-chlorophenyl)-2,2-dichloroethane (o, $\mathrm{p}^{\prime}$-DDD) by dog adrenal mitochondria and metabolite covalent binding to mitochondrial macromolecules: a possible mechanism for the adrenocorticolytic effect. Drug Metabolism and Disposition 5 482-486. 
Martz F \& Straw JA 1980 Metabolism and covalent binding of 1-(o-chlorophenyl)-1-(p-chlorophenyl)-2,2-dichloroethane (o,p'-DDD): correlation between adrenocorticolytic activity and metabolic activation by adrenocortical mitochondria. Drug Metabolism and Disposition 8 127-130.

Mathupala SP \& Pedersen PL 2010 Voltage dependent anion channel-1 (VDAC-1) as an anti-cancer target. Cancer Biology \& Therapy 9 1053-1056. (doi:10.4161/cbt.9.12.12451)

Metz SA 1973 Drug treatment of inoperable adrenocortical carcinoma. Journal of the American Medical Association 224 530. (doi:10.1001/jama. 224.4.530c)

Moore RN, Penney DP \& Averill KT 1980 Fine structural and biochemical effects of aminoglutethimide and o,p'-DDD on rat adrenocortical carcinoma 494 and adrenals. Anatomical Record 198 113-124. (doi:10.1002/ar.1091980109)

Samandari E, Kempná P, Nuoffer JM, Hofer G, Mullis PE \& Flück CE 2007 Human adrenal corticocarcinoma NCI-H295R cells produce more androgens than NCI-H295A cells and differ in 3ß-hydroxysteroid dehydrogenase type 2 and 17,20 lyase activities. Journal of Endocrinology 195 459-472. (doi:10.1677/JOE-07-0166)
Schteingart DE 2007 Adjuvant mitotane therapy of adrenal cancer - use and controversy. New England Journal of Medicine 356 2415-2418. (doi:10.1056/NEJMe078087)

Stigliano A, Cerquetti L, Borro M, Gentile G, Bucci B, Misiti S, Piergrossi P, Brunetti E, Simmaco M \& Toscano V 2008 Modulation of proteomic profile in H295R adrenocortical cell line induced by mitotane. Endocrine-Related Cancer 15 1-10. (doi:10.1677/ERC-07-0003)

Temple TE, Jr, Jones DJ, Jr, Liddle GW \& Dexter RN 1969 Treatment of Cushing's disease. Correction of hypercortisolism by o,p'DDD without induction of aldosterone deficiency. New England Journal of Medicine 281 801-805. (doi:10.1056/NEJM196910092811501)

Terzolo M, Angeli A, Fassnacht M, Daffara F, Tauchmanova L, Conton PA, Rossetto R, Buci L, Sperone P, Grossrubatscher E et al. 2007 Adjuvant mitotane treatment for adrenocortical carcinoma. New England Journal of Medicine 356 2372-2380. (doi:10.1056/NEJMoa063360)

Zaid H, Abu-Hamad S, Israelson A, Nathan I \& Shoshan-Barmatz V 2005 The voltage-dependent anion channel-1 modulates apoptotic cell death. Cell Death and Differentiation 12 751-760. (doi:10.1038/sj.cdd. 4401599)

Received in final form 29 May 2013

Accepted 30 May 2013

Made available online as an Accepted Preprint

30 May 2013
(C) 2013 Society for Endocrinology Printed in Great Britain
Published by Bioscientifica Ltd. 